\title{
Induksi Resistensi dengan Rhodotorula minuta untuk Mengendalikan Antraknosa (Colletotrichum acutatum J. H. Simmonds) Pada Tanaman Cabai
}

\author{
Sri Hartati ${ }^{{ }^{*}}$, Linda Tarina ${ }^{2}$, Endah Yulia ${ }^{1}$, dan Luciana Djaya ${ }^{1}$ \\ ${ }^{1}$ Departemen Hama dan Penyakit Tumbuhan, Fakultas Pertanian, Universitas Padjadjaran \\ Jl. Raya Bandung-Sumedang KM 21, Jatinangor, Indonesia 45363 \\ ${ }^{2}$ Program Studi Agroteknologi, Fakultas Pertanian, Universitas Padjadjaran \\ Jl. Raya Bandung-Sumedang KM 21, Jatinangor, Indonesia 45363 \\ *Email: s.hartati@unpad.ac.id
}

\begin{abstract}
Induced Resistance to Anthracnose (Colletotrichum acutatum J. H. Simmonds) by Rhodotorula minuta on Chili Plants
\end{abstract}

Anthracnose caused by Colletotrichum acutatum is a major disease of chili plants that may cause a big loss. The application of yeasts as resistance inducers on chili plants is an environmentallyfriendly control method. This study was carried out to evaluate the potency of Rhodotorula minuta in inducing resistance to anthracnose on chili plants. The experiment was carried out at the Laboratory of Plant Protection Biotechnology and Glass House at Ciparanje Research Station, Faculty of Agriculture, Universitas Padjadjaran, in Jatinangor and Laboratory of Biorin, PAU, Instititut Pertanian Bogor. The experiment was arranged in a randomized complete block design with 9 treatments and 5 replications. Induction of resistance by $R$. minuta was tested by inoculating tested chili plants with $C$. acutatum at different time of inoculation, i.e. 3, 5, 7, and 10 days after the induction treatments. The results of the experiment showed that $R$. minuta was able to induce resistance to anthracnose on chili plants. The smallest area of anthracnose symptom, of $0.1125 \mathrm{~cm}^{2}$, was found on leaves of treated plants by $R$. minuta inoculated at 7 days after treatment. Treatment of $R$. minuta on plants inoculated at 7 days after treatment showed the best induction response, the anthracnose suppression was $47.33 \%$, and the activity of peroxidase was increased by 1.7 times $\left(0.748 \Delta \mathrm{A}_{420} /\right.$ menit. $\mu \mathrm{g}$ protein).

Keywords: Yeast, Peroxidase, Induction response, Time of inoculation

\begin{abstract}
ABSTRAK
Antraknosa merupakan salah satu penyakit utama pada tanaman cabai yang menyebabkan kerugian cukup besar. Penggunaan khamir sebagai agens penginduksi resistensi tanaman cabai merupakan salah satu alternatif ramah lingkungan untuk pengendalian penyakit. Penelitian ini bertujuan untuk mengetahui kemampuan khamir $R$. minuta dalam menginduksi resistensi tanaman cabai untuk mengendalikan penyakit antraknosa cabai. Percobaan dilaksanakan di Laboratorium Bioteknologi Proteksi Tanaman dan Rumah Kaca Kebun Percobaan Ciparanje, Fakultas Pertanian, Universitas Padjadjaran di Jatinangor serta Laboratorium Biorin, PAU, Instititut Pertanian Bogor. Percobaan dilakukan menggunakan Rancangan Acak Kelompok (RAK) yang terdiri atas 9 perlakuan dan 5 ulangan. Pengaruh induksi resistensi diuji dengan perbedaan waktu inokulasi $C$. acutatum yaitu 3, 5, 7, dan 10 hari setelah perlakuan induksi. Hasil penelitian menunjukkan bahwa khamir $R$. minuta memiliki kemampuan menginduksi resistensi tanaman cabai terhadap antraknosa. Luas gejala antraknosa terkecil terjadi pada perlakuan induksi $R$. minuta dengan waktu inokulasi 7 hari setelah perlakuan yaitu sebesar $0,1125 \mathrm{~cm}^{2}$. Perlakuan $R$. minuta dengan waktu inokulasi 7 hari setelah perlakuan merupakan respon induksi terbaik dengan tingkat penekanan antraknosa sebesar 47,33\%, serta meningkatkan aktivitas enzim peroksidase 1,7 kali yaitu sebesar $0,748 \Delta \mathrm{A}_{420}$ /menit. $\mu \mathrm{g}$ protein.
\end{abstract}

Kata kunci: Khamir, Peroksidase, Respon induksi, Waktu inokulasi 


\section{PENDAHULUAN}

Cabai merah (Capsicum annuum L.) merupakan salah satu komoditas hortikultura yang memiliki nilai ekonomi tinggi. Produktivitas cabai di Indonesia dari tahun 2015-2017 berturut-turut 8,65 ton/ha, 8,47 ton/ha dan 8,46 ton/ha (BPS, 2017). Produktivitas cabai tersebut masih berada di bawah potensi produktivitas cabai yang bisa mencapai 1215 ton/ha (Duriat \& Agus, 2003). Berbagai kendala dalam budidaya tanaman cabai dapat menyebabkan menurunnya produktivitas cabai di Indonesia, salah satunya adalah serangan hama dan patogen. Salah satu patogen yang dapat menurunkan produktivitas cabai adalah Colletotrichum acutatum penyebab antraknosa. Penyakit antraknosa dapat menurunkan produksi cabai di Indonesia sebesar $10-80 \%$ pada musim hujan dan 2-35\% pada musim kemarau (Widodo, 2007).

Pengendalian penyakit antraknosa pada umumnya dilakukan dengan menggunakan fungisida sintetik (Marsuni \& Pramudi, 2016). Namun, penggunaan fungisida sintetik dapat berdampak buruk terhadap lingkungan tanah, air dan organisme non target (Aktar et al., 2009).

Salah satu cara pengendalian ramah lingkungan untuk penyakit tanaman adalah dengan melakukan induksi resistensi. Induksi resistensi adalah suatu proses untuk mengaktifkan resistensi alami tanaman inang melalui pemberian stimulan tertentu tanpa adanya introduksi gen-gen baru (Walters et al., 2007). Stimulan atau bahan penginduksi tersebut dapat berupa bahan kimia tertentu, mikroorganisme nonpatogen, patogen avirulen, ras patogen inkompatibel, dan patogen virulen yang gagal menginfeksi karena kondisi lingkungan yang tidak optimal (Vallad \& Goodman, 2004). Bahan penginduksi dapat menginduksi tanaman sehingga menghasilkan respon pertahanan yang diawali dengan terbentuknya oksigen reaktif (ROS) (Habibullah dkk., 2018).

Khamir merupakan salah satu mikroorganisme yang dapat digunakan sebagai agens penginduksi resistensi tanaman. Beberapa khamir telah dilaporkan dapat menginduksi resistensi tanaman terhadap berbagai penyakit tanaman. Khamir Rhodotorula mucilaginosa telah dilaporkan dapat menginduksi resistensi stroberi terhadap penyakit busuk lunak dan blue mold (Zhang et al., 2014). Khamir $R$. mucilaginosa juga dapat menginduksi resistensi buah apel terhadap penyakit gray mold dan blue mold (Li et al., 2011). Aureobasidium pullulans menginduksi resistensi buah apel terhadap penyakit gray mold dan blue mold (Ippolito et al., 2000). Metschnikowia fructicola menginduksi resistensi jeruk limau untuk mengendalikan Penicillium digitatum (Hershkovitz et al., 2012). Saccharomyces cerevisiae mampu menginduksi resistensi tanaman melalui peningkatan aktivitas peroksidase, polyphenoloxidase, fenilalanin amonia-lyase, $13-1,3$ glukanase dan kitinase secara lokal dan sistemik pada tanaman tomat, lada dan mentimun 11.

Menurut Bell (1988) dalam induksi resistensi, tanaman membutuhkan waktu untuk mengaktifkan sistem pertahanannya terhadap patogen. Candida saitoana dengan kerapatan $10^{8}$ $\mathrm{sel} / \mathrm{ml}$ dapat mengendalikan patogen Botritys cinerea pada buah apel sebesar $50-70 \%$ pada hari ke 7 setelah aplikasi khamir (El Ghaout et al., 2003). Pichia guilliermondii dengan kerapatan sel $10^{8}$ $\mathrm{sel} / \mathrm{ml}$ dapat menginduksi resistensi tanaman cabai terhadap penyakit antraknosa pada 3 hari setelah perlakuan khamir (Nantawanit, 2010). Hasil penelitian Zhang et al. (2014), menunjukkan bahwa khamir $R$. mucilaginosa dengan kerapatan sel $10^{8}$ $\mathrm{sel} / \mathrm{ml}$ dapat menginduksi resistensi buah stroberi terhadap penyakit busuk lunak (Rhizopus stolonifer) dan gray mold (Botrytis cinerea) pada 3 hari setelah perlakuan khamir. Khamir $R$. mucilaginosa dengan kerapatan sel $10^{8} \mathrm{sel} / \mathrm{ml}$ juga mampu menginduksi resistensi buah apel terhadap penyakit gray mold dan blue mold yang disebabkan oleh patogen Penicillium expansum dan B. cinerea pada 5 hari setelah perlakuan khamir.

Khamir $R$. minuta yang diisolasi dari buah cabai berpotensi sebagai agens antagonis patogen antraknosa pada cabai melalui mekanisme secara langsung (Hartati, 2016). Akan tetapi, kemampuan $R$. minuta tersebut dalam menginduksi resistensi tanaman cabai untuk penyakit yang sama belum diketahui. Penelitian ini bertujuan untuk mengetahui kemampuan khamir $R$. minuta dalam menginduksi resistensi tanaman cabai untuk mengendalikan penyakit antraknosa cabai.

\section{BAHAN DAN METODE}

Penelitian dilaksanakan di Laboratorium Bioteknologi Proteksi Tanaman, Departemen Hama dan Penyakit Tumbuhan, dan rumah kaca Kebun Percobaan Ciparanje, Fakultas Pertanian, Universitas Padjadjaran di Jatinangor. Rancangan penelitian yang digunakan adalah Rancangan Acak Kelompok (RAK) dengan 9 perlakuan dan 5 ulangan. Perlakuan tersebut menggunakan teknik perendaman benih dan penyiraman bibit cabai dengan suspensi $R$. 
minuta dengan waktu inokulasi patogen $C$. acutatum yang berbeda. Perlakuan yang diuji adalah sebagai berikut :

$\mathrm{A}=$ Perlakuan $R$. minuta dan inokulasi $C$. acutatum 3 hari setelah perlakuan (hsp)

$\mathrm{B}=$ Perlakuan $R$. minuta dan inokulasi $C$. acutatum 5 hsp

$\mathrm{C}=$ Perlakuan $R$. minuta dan inokulasi $C$. acutatum 7 hsp

$\mathrm{D}=$ Perlakuan $R$. minuta dan inokulasi $C$. acutatum 10 hsp

$\mathrm{E}=$ Kontrol (+) tanpa perlakuan $R$. minuta, inokulasi $C$. acutatum 3 hsp

$\mathrm{F}=$ Kontrol (+) tanpa perlakuani $R$. minuta, inokulasi $C$. acutatum 5 hsp

$\mathrm{G}=$ Kontrol (+) tanpa perlakuan $R$. minuta, inokulasi $C$. acutatum 7 hsp

$\mathrm{H}=$ Kontrol (+) tanpa perlakuan $R$. minuta, inokulasi C. acutatum 10 hsp

$\mathrm{I}=$ Kontrol $(-)$ tanpa perlakuan $R$. minuta dan inokulasi $C$. acutatum

\section{Penyediaan $R$. minuta dan $C$. acutatum}

Khamir $R$. minuta yang digunakan dalam penelitian ini diisolasi dari buah cabai dari pertanaman cabai di Darmaga Bogor. Jamur $C$. acutatum diisolasi dari tanaman cabai bergejala antraknosa dari pertanaman cabai di Sumedang. $R$. minuta diremajakan dalam media Yeast Malt Extract broth (YMB), selanjutnya ditumbuhkan pada media Potato Dextrose Agar (PDA). Media PDA juga digunakan untuk perbanyakan jamur $C$. acutatum. Suspensi khamir dibuat dari biakan murni khamir berumur 5 hari dengan kerapatan sel $10^{8} \mathrm{sel} / \mathrm{ml}$, sedangkan suspensi $C$. acutatum dibuat dari biakan murni jamur berumur 10 hari dengan kerapatan konidia $10^{6}$ konidia/ml. Kerapatan sel khamir dan jamur dihitung dengan menggunakan haemasitometer.

\section{Persiapan Benih Cabai}

Benih cabai yang digunakan adalah varietas Unpad CB-2 koleksi Dr. Ir. Neni Rostini, MS. Laboratorium Pemuliaan Tanaman dan Produksi Tanaman. Varietas cabai tersebut merupakan hasil persilangan Capsicum frutescens dengan varietas Unpad CB 1 yang keturunannya disilangkan dengan cabai keriting lokal kode seleksi 1-7-2-2 atau RM08 AXKRTRM 1B (Kementerian Pertanian, 2015).

\section{Perlakuan Induksi Resistensi}

Benih cabai direndam dalam air hangat selama \pm 4 jam sebelum diberi perlakuan induksi untuk memudahkan benih berkecambah. Setelah direndam air hangat, benih cabai ditiriskan selanjutnya diberi perlakuan induksi. Perlakuan induksi dilakukan dengan merendam benih cabai dalam suspensi khamir $R$. minuta kerapatan $10^{8}$ $\mathrm{sel} / \mathrm{ml}$ selama 60 menit. Selanjutnya, benih diperam selama 12 jam dalam kertas tissue steril lembab. Perlakuan kontrol dilakukan dengan merendam benih dalam akuades steril.

Benih cabai berperlakuan kemudian disemai pada media semai siap pakai "Fam Organic" dalam polibag berukuran 10x15 cm. Media semai ini merupakan campuran dari tanah, sekam bakar, cocopeat dan pupuk kascing. Bibit cabai berumur 5 minggu dipindah ke polibag berukuran 20x25 cm dan diinduksi kembali dengan suspensi khamir dengan cara menyiramkan suspensi khamir sebanyak $30 \mathrm{ml}$ per bibit (kerapatan $10^{8} \mathrm{sel} / \mathrm{ml}$ ). Media tanam yang digunakan untuk pindah tanam berupa campuran tanah dengan pupuk kandang sapi dengan perbandingan 2:1. Pupuk yang digunakan adalah urea (200 kg/ha), Za (450 kg/ha), SP 36 (150 $\mathrm{kg} / \mathrm{ha})$, dan KCl (150 kg/ha) (Setiadi, 2006).

\section{Inokulasi Patogen}

Inokulasi patogen C. acutatum dilakukan sesuai perlakuan waktu inokulasi yaitu $3,5,7$, dan 10 hari setelah perlakuan penginduksian pada bibit cabai (hsp). Inokulasi patogen $C$. acutatum dilakukan pada tanaman cabai sehat. Daun tanaman cabai sehat diinokulasi patogen dengan cara meneteskan suspensi $C$. acutatum dengan kerapatan $10^{6} \mathrm{konidia} / \mathrm{ml}$ sebanyak $0,1 \mathrm{ml} /$ daun. Inokulasi tersebut dilakukan pada luka yang dibuat dengan jarum steril. Tanaman yang telah diinokulasi disungkup menggunakan kantung plastik untuk menjaga kelembaban.

\section{Analisis Aktivitas Enzim Peroksidase}

Aktivitas enzim peroksidase diuji berdasarkan metode Kar \& Mishra (1976). Analisis enzim dilakukan pada daun cabai empat hari setelah inokulasi (Li et al., 2011). Supernatan dibuat dari 0,5 gram daun cabai yang digerus sampai halus dan ditambahkan 0,05 M buffer fosfat ( $\mathrm{pH}$ 7) dengan perbandingan 1:4 (g/ml), kemudian disaring menggunakan kertas saring Whatman no. 1. Filtrat daun cabai yang didapatkan disentrifugasi pada suhu $4^{\circ} \mathrm{C}$ selama 10 menit dengan kecepatan $5000 \mathrm{rpm}$. Supernatan yang diperoleh digunakan sebagai sediaan enzim.

Sediaan enzim sebanyak $100 \mu \mathrm{l}$ ditambah $2,5 \mathrm{ml}$ pirogalol 0,2 M direaksikan dengan $250 \mu \mathrm{l}$ $\mathrm{H}_{2} \mathrm{O}_{2}$ 1\%. Absorbansi diukur pada panjang 
gelombang $420 \mathrm{~nm}$ dengan spektrofotometer setiap 30 detik dalam periode 0-240 detik. Blanko merupakan larutan yang sama ditambah 0,05 M buffer fosfat ( $\mathrm{pH}$ 7) tanpa sediaan enzim. Peningkatan nilai absorbansi persatuan waktu per bobot protein $\left(\Delta \mathrm{A}_{420} /\right.$ menit.mg protein $)$ yang didapatkan merupakan nilai aktivitas peroksidase.

Total protein dianalisis menggunakan metode Lowry (1951). Sediaan enzim sebanyak $1 \mathrm{ml}$ dicampur dengan $5 \mathrm{ml}$ pereaksi $\mathrm{C}$ lalu diinkubasi pada suhu ruang selama 10 menit, selanjutnya ditambah 0,5 $\mathrm{ml}$ pereaksi $\mathrm{D}$ dan diinkubasi pada suhu ruang selama 30 menit. Absorbansi diukur menggunakan spektrofotometer pada panjang gelombang $500 \mathrm{~nm}$. Kadar protein sampel dihitung dari nilai absorbansi dengan konstanta dan koefisien persamaan regresi linier pada kurva standar BSA.

\section{Pengamatan Masa Inkubasi dan Persentase Penekanan Gejala}

Masa inkubasi diamati untuk mengetahui waktu dari inokulasi patogen sampai muncul gejala penyakit pertama kali. Tanaman yang telah diinokulasi dengan $C$. acutatum diamati setiap hari sampai muncul gejala pertama pada semua perlakuan.

Persentase penekanan gejala antraknosa pada daun cabai diukur berdasarkan luas gejala yang muncul pada saat masa inkubasi. Luas gejala diukur menggunakan plastik transparan berpetak dengan ukuran 0,5 cm x 0,5 cm (Sasmita, 2015). Perhitungan luas gejala pada daun menggunakan rumus sebagai berikut:

Luas gejala $=$ Jumlah petak bergejala $\mathrm{x}$ luas petak

Persentase penekanan gejala dihitung berdasarkan rumus sebagai berikut:

$$
\text { Penekanan gejala }(\%)=\frac{\text { LGk }- \text { LGp }}{\text { LGk }} \times 100 \%
$$

Keterangan:

LGk = Luas gejala antraknosa pada kontrol

LGp = Luas gejala antraknosa pada perlakuan

\section{Pengamatan Aktivitas Enzim Peroksidase}

Aktivitas peroksidase diamati pada perlakuan waktu inokulasi patogen $7 \mathrm{hsp}$. Perhitungan aktivitas enzim peroksidase berdasarkan rumus Kar \& Mishra (1976).
$\mathrm{UAE}=\frac{\Delta \mathrm{OD} \times \text { sediaan enzim }(\mathrm{ml})}{\text { Jumlah protein }(\mathrm{mg}) \mathrm{x} \text { waktu inkubasi (menit) }} \times \mathrm{Fp}(\mathrm{x})$

Keterangan:

$\Delta \mathrm{OD}=$ Koefisien regresi persamaan linear nilai absorbansi dan waktu inkubasi $(\mathrm{Y}=\mathrm{a}+\mathrm{bx})$

$\mathrm{Fp}(\mathrm{x})=$ Faktor pengenceran sampel

Penentuan kadar protein terlarut dilakukan berdasarkan rumus Lowry et al. (1951).

$$
\text { Jumlah protein }=\frac{\text { Nilai absorbansi }-\mathrm{a}}{\mathrm{b}} \mathrm{x} \mathrm{Fp}(\mathrm{x})
$$

Keterangan:

Nilai $\mathrm{a}=$ Konstanta regresi persamaan linear kurva standar BSA $(\mathrm{Y}=\mathrm{a}+\mathrm{bx})$

Nilai $b=$ Koefisien regresi persamaan linear kurva standar BSA $(\mathrm{Y}=\mathrm{a}+\mathrm{bx})$

$\mathrm{Fp}(\mathrm{x})=$ Faktor pengenceran sampel

\section{Analisis Data}

Data yang diperoleh dianalisis dengan Analysis of Variance (ANOVA) menggunakan program SPSS Versi 22.0 for windows. Jika terdapat pengaruh perlakuan, maka dilakukan uji lanjut dengan Uji Jarak Berganda Duncan pada taraf nyata $5 \%$.

\section{HASIL DAN PEMBAHASAN}

\section{Pengaruh Induksi oleh $R$. minuta terhadap Masa Inkubasi Penyakit Antraknosa}

Perlakuan induksi resistensi tanaman cabai oleh khamir $R$. minuta tidak mempengaruhi waktu inkubasi penyakit antraknosa. Gejala antraknosa muncul pada 7 hari setelah inokulasi pada semua perlakuan (Tabel 1).

Waktu inkubasi penyakit antraknosa dalam penelitian ini termasuk cepat. Menurut Herwidyarti dkk. (2013) waktu inkubasi penyakit antraknosa adalah 12 hari. Hal tersebut menunjukkan bahwa virulensi $C$. acutatum yang digunakan cukup tinggi. Terbentuknya gejala antraknosa oleh $C$. acutatum juga disebabkan oleh jumlah inokulum yang cukup yaitu dengan kerapatan konidia $10^{6}$ konidia $/ \mathrm{ml}$. Selain virulensi patogen dan jumlah inokulum, masa inkubasi penyakit juga dipengaruhi oleh kondisi lingkungan. Gejala antraknosa pada cabai didukung oleh kondisi lingkungan yang optimal yaitu suhu sekitar $27^{\circ} \mathrm{C}$ dan kelembaban diatas $80 \%$ (Meilin 2014). Suhu dan kelembaban yang sama juga terjadi pada lokasi penelitian. 
Tabel 1. Masa inkubasi penyakit antraknosa pada tanaman cabai dengan perlakuan induksi resistensi $R$. minuta

\begin{tabular}{|c|c|}
\hline Perlakuan & $\begin{array}{c}\text { Masa inkubasi penyakit } \\
\text { (hari) }\end{array}$ \\
\hline$R$. minuta, inokulasi $C$. acutatum 3 hari setelah perlakuan (hsp) & 7 \\
\hline$R$. minuta, inokulasi $C$. acutatum 5 hsp & 7 \\
\hline$R$. minuta, inokulasi $C$. acutatum 7 hsp & 7 \\
\hline R. minuta, inokulasi $C$. acutatum 10 hsp & 7 \\
\hline Kontrol + (Tanpa $R$. minuta, inokulasi $C$. acutatum 3 hsp) & 7 \\
\hline Kontrol + (Tanpa $R$. minuta, inokulasi $C$. acutatum 5 hsp) & 7 \\
\hline Kontrol + (Tanpa $R$. minuta, inokulasi $C$. acutatum 7 hsp) & 7 \\
\hline Kontrol + (Tanpa $R$. minuta, inokulasi $C$. acutatum $10 \mathrm{hsp})$ & 7 \\
\hline
\end{tabular}

Tidak adanya penundaan masa inkubasi pada perlakuan induksi oleh $R$. minuta diduga karena respon induksi terjadi ketika gejala tanaman muncul. Hal tersebut terjadi karena tanaman yang diberi perlakuan induksi resistensi memerlukan waktu untuk mengaktifkan sistem pertahanannya (Bell, 1988).

\section{Pengaruh Induksi oleh $R$. minuta terhadap Luas} Gejala Antraknosa dan Penekanan Penyakit

Luas gejala antraknosa diukur sesuai dengan masa inkubasi penyakit yaitu pada 7 hari setelah inokulasi (hsi). Gejala antraknosa yang terjadi seperti yang dilaporkan oleh Coates et al. (2016) yaitu timbulnya lesio berwarna coklat sampai coklat tua atau hitam, bentuk lesio tidak beraturan, dan terdapat halo berwarna kuning pada bagian pinggirnya. Seiring dengan perkembangan gejala, lesio tersebut akan berbentuk cekung dan mengarah ke tepi daun.

Berdasarkan hasil pengamatan diketahui bahwa pada 7 hsi rata-rata luas gejala antraknosa terbesar terjadi pada kontrol positif dengan inokulasi C. acutatum pada 5 dan 10 hari setelah perlakuan (hsp) yaitu sebesar $0,2750 \mathrm{~cm}^{2}$. Adapun rata-rata luas gejala antraknosa terkecil terjadi pada perlakuan $R$. minuta dengan inokulasi $C$. acutatum pada 7 hsp yaitu sebesar $0,1125 \mathrm{~cm}^{2}$ (Tabel 2). Tanaman cabai yang tidak diinduksi dan tidak diinokulasi patogen (kontrol negatif) tidak menunjukkan gejala penyakit antraknosa dari awal sampai akhir pengamatan.

Tabel 2. Luas gejala penyakit antraknosa daun cabai pada 7 hari setelah inokulasi (hsi) dengan perlakuan induksi resistensi $R$. minuta

\begin{tabular}{|c|c|}
\hline Perlakuan & Rata-rata luas gejala $\left(\mathrm{cm}^{2}\right)$ \\
\hline$R$. minuta, inokulasi $C$. acutatum $3 \mathrm{hsp}$ & $0,2375 \mathrm{c}$ \\
\hline R. minuta, inokulasi $C$. acutatum 5 hsp & $0,2375 \mathrm{c}$ \\
\hline$R$. minuta, inokulasi $C$. acutatum 7 hsp & $0,1125 \mathrm{ab}$ \\
\hline R. minuta, inokulasi $C$. acutatum $10 \mathrm{hsp}$ & $0,1625 \mathrm{bc}$ \\
\hline Kontrol + (Tanpa $R$. minuta, inokulasi $C$. acutatum 3 hsp) & $0,2500 \mathrm{c}$ \\
\hline Kontrol + (Tanpa $R$. minuta, inokulasi $C$. acutatum 5 hsp) & $0,2750 \mathrm{c}$ \\
\hline Kontrol + (Tanpa $R$. minuta, inokulasi $C$. acutatum 7 hsp) & $0,2625 \mathrm{c}$ \\
\hline Kontrol + (Tanpa $R$. minuta, inokulasi $C$. acutatum $10 \mathrm{hsp})$ & $0,2750 \mathrm{c}$ \\
\hline Kontrol - (Tanpa $R$. minuta dan inokulasi $C$. acutatum) & $0,0000 \mathrm{a}$ \\
\hline
\end{tabular}

Berdasarkan analisis statistik diketahui bahwa perlakuan induksi resistensi oleh $R$. minuta berpengaruh terhadap luas gejala antraknosa. Luas gejala antraknosa pada perlakuan $R$. minuta dengan inokulasi $C$. acutatum 7 hsp berbeda nyata dengan seluruh perlakuan kecuali dengan perlakuan $R$. minuta dengan inokulasi $C$. acutatum $10 \mathrm{hsp}$.
Sementara itu, terdapat perbedaan yang nyata antara kontrol negatif dengan seluruh perlakuan kecuali dengan perlakuan $R$. minuta dengan inokulasi $C$. acutatum pada 7 hsp (Tabel 2).

Hasil pengamatan luas gejala tersebut sesuai dengan persentase penekanan gejala antraknosa (Tabel 3). Persentase penekanan penyakit terbesar 
terjadi pada perlakuan $R$. minuta dengan inokulasi C. acutatum 7 hsp yaitu sebesar $47,33 \%$ sedangkan persentase penekanan penyakit antraknosa terkecil terjadi pada perlakuan $R$. minuta dengan inokulasi C. acutatum 3 hsp yaitu sebesar 5,67\%.

Hasil penelitian ini menunjukkan bahwa respon induksi resistensi pada tanaman cabai terjadi pada hari ke-3 sampai ke-10 setelah aplikasi $R$. minuta. Respon induksi resistensi terbaik terjadi pada perlakuan $R$. minuta dengan inokulasi $C$. acutatum 7 hsp (Tabel 3).

Penekanan perkembangan luas gejala antraknosa pada tanaman cabai akibat perlakuan induksi resistensi oleh $R$. minuta diduga disebabkan oleh adanya peningkatan aktivitas enzim pertahanan. Enzim yang berkaitan dengan pertahanan tanaman biasanya meningkat setelah adanya inokulasi patogen pada tanaman yang diinduksi. Hal ini sesuai dengan dasar pemikiran induksi resistensi yang menyatakan bahwa reaksi pertahanan tanaman tidak diekspresikan sebelum induksi resistensi diberikan dan ekspresi ketahanan akan muncul setelah adanya infeksi patogen pada waktu dan lokasi yang berbeda (Olivera et al., 2016).

Tabel 3. Persentase penekanan penyakit antraknosa pada tanaman cabai dengan perlakuan induksi resistensi $R$. minuta

\begin{tabular}{lc}
\hline \multicolumn{1}{c}{ Perlakuan } & Penekanan penyakit (\%) \\
\hline R. minuta, inokulasi $C$. acutatum 3 hsp & 5,67 \\
$R$. minuta, inokulasi $C$. acutatum 5 hsp & 15,67 \\
R. minuta, inokulasi $C$. acutatum 7 hsp & 47,33 \\
R. minuta, inokulasi $C$. acutatum $10 \mathrm{hsp}$ & 34,67 \\
\hline
\end{tabular}

Selain disebabkan oleh peningkatan enzim pertahanan, terhambatnya perkembangan luas gejala antraknosa pada tanaman cabai bisa disebabkan tanaman yang terinduksi menghasilkan senyawa metabolit sekunder yang dapat meningkatkan ketahanan tanaman. Bahan penginduksi dapat mengaktifkan jalur sekunder tanaman dalam merespon stres dan serangan patogen (Sharma et al., 2009). Selain itu, agens penginduksi resistensi juga dapat meningkatkan hormon pertumbuhan tanaman sehingga pertumbuhan tanaman menjadi lebih baik dan sulit untuk diinfeksi patogen (Gao et al., 2010).

\section{Pengaruh Induksi oleh $R$. minuta terhadap Peningkatan Aktivitas Enzim Peroksidase}

Hasil pengamatan menunjukkan bahwa terjadi peningkatan aktivitas enzim peroksidase yang tinggi pada tanaman yang diinduksi oleh $R$. minuta (Gambar 1). Aktivitas enzim peroksidase pada tanaman cabai dengan perlakuan $R$. minuta dan inokulasi $C$. acutatum pada 7 hsp meningkat sebesar 1,7 kali dibandingkan dengan perlakuan inokulasi $C$. acutatum tanpa induksi khamir $(0,748$ $\Delta \mathrm{A}_{420}$ /menit. $\mu$ g protein).

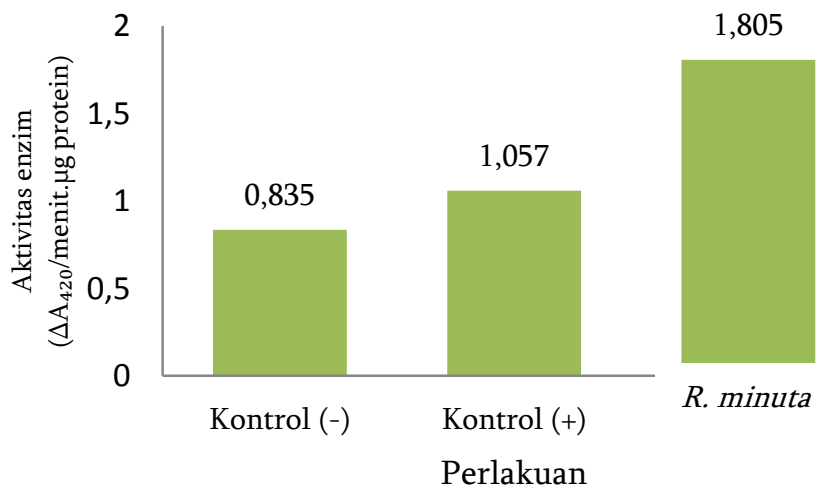

Gambar 1. Aktivitas enzim peroksidase tanaman cabai dengan perlakuan induksi $R$. minuta dan inokulasi C. acutatum 7 hsp

Kenaikan aktivitas enzim tersebut sesuai perlakuan induksi resistensi tanaman cabai dengan dengan penelitian Taufik dkk. (2010) bahwa PGPR (Plant Growth Promoting Rhizobacteria) 
terhadap penyakit cucumber mozaik virus dapat meningkatkan aktivitas enzim peroksidase 1,7 kali lebih tinggi dari perlakuan kontrol pada 7 hari setelah perlakuan. Selain itu, penelitian Ippolito et al. (2000) melaporkan bahwa khamir Aureobasidium pullulans dengan kerapatan sel $10^{7} \mathrm{sel} / \mathrm{ml}$ dapat menginduksi resistensi buah apel untuk mengendalikan penyakit gray mold dan blue mold dan dapat meningkatkan aktivitas enzim peroksidase 6 kali lebih tinggi dibandingkan kontrol.

Terjadinya peningkatan aktivitas enzim peroksidase pada penelitian ini, sejalan dengan penekanan luas gejala antraknosa. Peningkatan aktivitas enzim peroksidase pada perlakuan induksi dengan $R$. minuta dan inokulasi $C$. acutatum 7 hsp dapat memperkecil luas gejala antraknosa yang muncul pada daun cabai hingga $0,1125 \mathrm{~cm}^{2}$ (Tabel 2) dan menekan penyakit dengan persentase penekanan yang paling tinggi yaitu 47,33\% (Tabel 3).

Aktivitas enzim peroksidase juga terdeteksi pada tanaman kontrol negatif yaitu sebesar 0,835 $\Delta \mathrm{A}_{420} /$ menit. $\mu$ g protein. Adanya aktivitas enzim peroksidase pada tanaman yang tidak diberi perlakuan induksi $R$. minuta maupun inokulasi $C$. acutatum menunjukkan bahwa enzim peroksidase secara alami terdapat pada tanaman. Menurut Siegel (1993) enzim peroksidase banyak terdistribusi di alam dan dapat ditemukan pada tanaman, hewan dan mikroorganisme. Enzim peroksidase pada tanaman cabai selain berperan dalam sistem pertahanan tanaman, juga dapat berperan sebagai katalisator reaksi oksidatif capsaicinoid dalam menghasilkan capsaicin (Diaz et al., 2004).

Enzim peroksidase merupakan indikator terjadinya induksi resistensi baik secara lokal maupun sistemik (El-Mougy et al., 2013). Perananan enzim peroksidase dalam sistem pertahanan tanaman diantaranya adalah memperkuat dinding sel melalui pembentukan protein struktural pada dinding sel tanaman dan biosintesis lignin (Stermer, 1995). Vidhyasekaran (2004) menyatakan bahwa enzim peroksidase berperan sebagai katalis dalam polimerasi monolignol untuk membentuk dinding sel tanaman. Selain itu, enzim peroksidase dapat berperan sebagai katalis reaksi oksidasi senyawa fenolik menjadi senyawa kuinon dan menghasilkan $\mathrm{H}_{2} \mathrm{O}_{2}$ yang toksik bagi patogen (Turk, 1993). Menurut Bell (1988) enzim peroksidase juga dapat mengkatalisasi pembentukan senyawa-senyawa metabolit sekunder yang bersifat toksik sebagai reaksi adanya serangan patogen.
Reaksi pertahanan tanaman dihasilkan akibat adanya elisitor yang berperan dalam pembentukan dan transduksi sinyal yang diterima oleh reseptor pada tanaman. Hindumathy (2012) menyatakan bahwa interaksi elisitor dengan reseptor diduga menghasilkan sinyal yang mengaktifkan respon pertahanan tanaman. Sel-sel khamir $R$. minuta maupun senyawa-senyawa yang dihasilkannya diduga berperan sebagai elisitor. Menurut Sharma et al. (2009) fragmen oligosakarida yang berasal dari polisakarida dinding sel khamir diketahui berperan sebagai elisitor yang aktif menginduksi respon pertahanan inangnya

Mekanisme resistensi tanaman cabai dengan perlakuan induksi oleh $R$. minuta dan inokulasi $C$. acutatum pada 7 hsp diduga tidak hanya berasal dari aktivitas enzim peroksidase saja. Respon pertahanan tanaman dapat menghasilkan enzim yang terkait dengan stres seperti fenilalanin amonia-lyase (PAL) dan akumulasi enzim pengoksidasi komponen fenolik seperti peroksidase, polifenoloksidase, sintesis enzim glucanohydrolase seperti kitinase dan $\beta$-1,3-glucanase (Park \& Kloepper, 2000; Hindumathy, 2012). Shan et al. (2014) melaporkan bahwa isolat khamir XL-1 dapat meningkatkan enzim yang berkaitan dengan resistensi tanaman yaitu polyphenoloxidase, SOD, dan $\beta$-1, 3- glucanase pada buah melon.

\section{SIMPULAN}

1. Khamir $R$. minuta mampu menginduksi resistensi tanaman cabai untuk mengendalikan antraknosa yang disebabkan oleh Colletotrichum acutatum.

2. Respon induksi resistensi terbaik terjadi pada 7 hari setelah perlakuan $R$. minuta dengan persentase penekanan antraknosa tertinggi sebesar $47,33 \%$.

3. Terjadi peningkatan aktivitas enzim peroksidase pada perlakuan $R$. minuta dengan inokulasi $C$. acutatum 7 hsp sebesar $0,748 \Delta \mathrm{A}_{420} /$ menit. $\mu \mathrm{g}$ protein.

\section{UCAPAN TERIMA KASIH}

Ucapan terimakasih disampaikan kepada Direktorat Riset dan Pengabdian Kepada Masyarakat dan Inovasi Universitas Padjadjaran yang telah mendanai kegiatan ini melalui Riset Fundamental Unpad Program Hibah Internal Universitas Tahun Anggaran 2018. 


\section{DAFTAR PUSTAKA}

Aktar, M, Wasim, D Sengupta, and A Chowdhury. 2009. Impact of pesticides use in agriculture: their benefits and hazards. Journal Interdisciplinary Toxicology. 2(1): $1-12$.

Bell, AA. 1988. Biochemical mechanisms of diseases resistance. Annual Review Plant Physiology. 32: 21-28.

BPS. 2017. Produktivitas Cabai Besar. Badan Pusat Statistik. Tersedia online pada http: www.pertanian.go.id/ap_pages/mod/dataho rti. Diakses pada 22 Mei 2018.

Coates, L, T Cooke, and L Forsberg. 2016. The Biology and Management of Colletotrichum Disease in Production Nurseries. Department of Agriculture, Fisheries and Forestry. Australia. 6 pp.

Diaz, J, F Pomar, A Bernali, and F Merino. 2004. Peroxidases and metabolism of capsaicin in Capsicum anuum L. Phytochemistry Reviews. 3: 141-157.

Duriat, A, dan M Agus. 2003. Pengenalan Penyakit Penting Pada Cabai dan Pengendaliannya Berdasarkan Epidemologi Terapan. Balai Penelitian Tanaman Sayuran.

El-Ghaouth, A, CL Wilson, and M Wisniewski. 2003. Control of postharvest decay of apple fruit with Candida saitoana and induction of defense responses. Phytopathology. 93: 344-348.

El-Mougy, NS, MM Abdel-Kader, SM Lashin, and AA Megahed. 2013. Fungicides alternatives as plant resistance inducers against foliar diseases incidence of some vegetables grown under plastic houses conditions. International Journal of Engineering and Innovative Technology (IJEIT). 3:71-81 .

Gao, FK, CC Dai, and XZ Liu. 2010. Mechanisms of fungal endophytes in plant protection against pathogens. African Journal of Microbiology Research. 4: 1346-1351.

Habibullah, M, A Widiastuti, dan C Sumardiyono. 2018. Respons awal ketahanan jagung terhadap Peronosclerospora maydis dan induksi bahan kimia. Jurnal Perlindungan Tanaman Indonesia. 22: 27-32.

Hartati, S. 2016. Khamir sebagai Agens Biokontrol Antraknosa (Colletotrichum acutatum J. H. Simmonds) pada Cabai Pascapanen. [Disertasi]. Sekolah Pascasarjana Institut Pertanian Bogor. Bogor.

Hershkovitz, V, C Ben-Dayan, G Raphael, M
Pasmanik-Chor, J Liu, E Belausov, R Aly, M Wisniewski, and S Droby. 2012. Global changes in gene expression of grapefruit peel tissue in response to the yeast biocontrol agent Metschnikowia fructicola. Molecular Plant Pathology. 13: 338-349.

Herwidyarti, KH, S Ratih dan DRJ Sembodo. 2013. Keparahan penyakit antraknosa pada cabai (Capsicum annum L.) dan berbagai jenis gulma. Jurnal Agrotek Tropika. 1(1): 102106.

Hindumathy, CK. 2012. The defense activator from yeast for rapid induction of resistance in suseptible pearl millet hybrid against downy mildew disease. International Journal of Agriculture Sciences 4: 196-201. Tersedia online pada http://www.bioinfo.in/contents.php. Diakses pada 15 Juni 2019.

Ippolito, A, AE Ghaouth, CL Wilson, and $\mathrm{M}$ Wisniewski. 2000. Control of postharvest decay of apple fruit by Aureobasidium pullulans and induction of defense responses. Postharvest Biology and Technology. 19: 265-272.

Ippolito, A, AE Ghaouth, CL Wilson, and $\mathrm{M}$ Wisniewski. 2000. Control of postharvest decay of apple fruit by Aureobasidium pullulans and induction of defense responses. Postharvest Biology and Technology. 19: 265-272.

Kar, M, and D Mishra. 1976. Catalase, peroksidase, and polyphenoloxidase activities during rice leaf senescence. Plant Physiolog., 57: 315319.

Kementerian Pertanian. 2015. Deskripsi Cabai Varietas Unpad CB-2. Surat Keputusan Menteri Pertanian Nomor 032/Kpts/SR.120/D. 2. 7/3/2015.

Li, R, H Zhang, W Liu, and X Zheng. 2011. Biocontrol of postharvest gray and blue mold decay of apples with Rhodotorula mucilaginosa and possible mechanism of action. International Journal of Food Microbiology. 146(2): 151-156.

Li, R, H Zhang, W Liu, and X Zheng. 2011. Biocontrol of postharvest gray and blue mold decay of apples with Rhodotorula mucilaginosa and possible mechanism of action. International Journal of Food Microbiology. 146(2): 151-156.

Lowry, OH, NJ Rosebrough, AL Farr, and RJ Randall. 1951. Protein measurement with 
the folin phenol reagent. Journal Biology Chemical. 193: 265-275.

Marsuni, Y, dan MI Pramudi. 2016. Pengendalian penyakit antraknosa pada cabai dengan budidaya tanaman yang ramah lingkungan. Jurnal Fitopatologi Indonesia. 26(1): 4-14.

Meilin, A. 2014. Hama dan Penyakit pada Tanaman Cabai dan Pengendaliannya. Balai Pengkajian Teknologi Pertanian Jambi. 26 hlm.

Nantawanit, N, A Chanchaichaovivat, B Panijpan, and $\mathrm{P}$ Ruenwongsa. 2010. Induction of defense response against Colletotrichum capsici in chilli fruit by the yeast Pichia guilliermondii strain R13. Journal Biological Control. 52: 145-152.

Olivera, MDM, CMR Varanda, and MRF Félix. 2016. Induced resistance during the interaction pathogen $\mathrm{X}$ plant and the use of resistance inducers. Phytochemistry Letters reviews. 15: 152-158.

Park, KS, and JW Kloepper. 2000. Activation of PR1a promoter by Rhizobacteria that induced systemic resistance in tobacco against Pseudomonas syringae pv. Tabaci. Journal Biological Control. 18(1):2-9.

Sasmita, M. 2015. Skrining PGPR sebagai Agens Pengendali Hayati Antraknosa Colletotricum dematium var. truncatum pada Kedelai. [Skripsi]. Departemen Proteksi Tanaman Fakultas Pertanian Institut Pertanian Bogor, Bogor.

Setiadi. 2006. Bertanam Cabai. Penebar Swadaya. Jakarta. 184 hlm.

Shan, CH, W Chen, H Zhang, F-X Tang, and J-M Tong. 2014. Effecton antagonistic yeast XL1 on resistance-associated enzyme activities in postharvest cantaloupe. Genetics and Molecular Research. 13: 6253- 6258.

Sharma, RR, D Singh, and R Singh. 2009. Biological control of postharvest diseases of fruits and vegetables by microbial antagonists. Biological Control. 50: 205221.

Siegel, BZ. 1993. Plant peroxidases: an organismic perspective. Journal Plant Growth Regulation. 12(3): 303-312.

Stermer, BA. 1995. Molecular regulation of systemic induced resistance. Pp. 111-140 in: Induced
Resistance to Disease in Plant. ( $\mathrm{R}$ Hammerschmidt, and J Kuc, Eds.). Kluwer Academic Publisher, Dordrecht.

Taufik, M, A Rahman, A Wahab, and SH Hidayat. 2010. Mekanisme ketahanan terinduksi oleh Plant growth promotting rhizobacteria (PGPR) pada tanaman cabai terinfeksi Cucumber Mosaik Virus (CMV). Jurnal Hortikultura. 20: 274-283.

Turk, JE, C Breda, D Buffard, C Sallaud, RS Esnault, and A Kondorosi. 1993. Analysis of Peroxidase Gene Expression in an Hypersensitive Response Induced by Pathogenic Bacteria on Alfalfa. Kluwer Academic Publisher, Dordrecht. 356 pp.

Vallad, G, and RM Goodman. 2004. Systemic acquire resistance and induced systemic resistance in conventional agriculture. Crop Science. 44: 124-129.

Vidhyasekaran, P. 2004. Concise Enclycolpedia of Plant Pathology. Food Product Press and Howard Reference Press. London. 619 pp.

Walters, D, A Newton, and G Lyon. 2007. A Sustainable Approach to Crop Protection. Blackwell Publishing. UK. 273 pp.

Widodo. 2007. Status of chili antrachnose in Indonesia. In First International Symposium and Chili Anthracnose. National Horticultural Research Institute, Rural Development of Administration. Republic of Korea.

Zhang, H, L Ge, K Chen, L Zhao, and X Zhang. 2014. Enhanced biocontrol activity of Rhodotorula mucilaginosacultured in media containing chitosan against postharvest diseases in strawberries: Possible mechanisms underlying the effect. Journal Agriculture Food Chemical. 62(18): 4214-4224.

Zhang, H, L Ge, K Chen, L Zhao, and X Zhang. 2014. Enhanced biocontrol activity of Rhodotorula mucilaginosacultured in media containing chitosan against postharvest diseases in strawberries: Possible mechanisms underlying the effect. Journal Agriculture Food Chemical. 62(18): 4214-4224. 